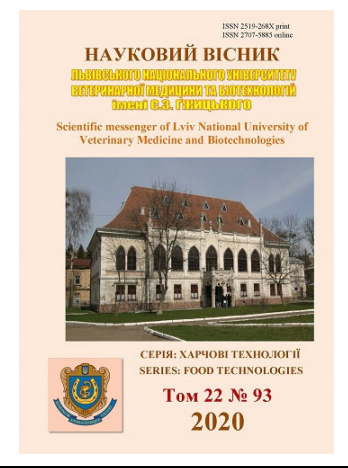

\author{
Науковий вісник Аьвівського національного університету \\ ветеринарної медицини та біотехнологій імені С.3. Гжицького. \\ Серія: Харчові технології \\ Scientific Messenger of Lviv National University \\ of Veterinary Medicine and Biotechnologies. \\ Series: Food Technologies
}

ISSN 2519-268X print ISSN 2707-5885 online doi: 10.32718/nvlvet-f9306

https://nvlvet.com.ua/index.php/food

UDC 664.665:664.644.2:546.41-386

\title{
Functional wheat bread with calcium chelate complexes
}

\author{
A. Kapustian, N. Cherno, T. Lebedenko \\ Odesa National Academy of Food Technologies, Odesa, Ukraine
}

Article info

Received 24.01.2020

Received in revised form 25.02.2020

Accepted 26.02.2020

Odesa National Academy of Food Technologies, Odesa, Kanatna Str., 112, 65039, Ukraine. Tel.: +38-096-758-88-34 E-mail:fst.journal@ukr.net
Kapustian, A., Cherno, N., \& Lebedenko, T. (2020). Functional wheat bread with calcium chelate complexes. Scientific Messenger of Lviv National University of Veterinary Medicine and Biotechnologies. Series: Food Technologies, 22(93), 31-38. doi: 10.32718/nvlvet-f9306

Bakery products are promising objects for enrichment with functional food ingredients, as they are mass consumption products. The problem of hypo-elementosis in people makes it advisable to develop functional food ingredients based on easily digestible and safe forms of essential biometals, including calcium. In this study, it has been shown that wheat bread can be enriched with calcium chelate complexes. This functional food ingredient was obtained by complexation of $\mathrm{Ca}^{2+}$ with bioligands of probiotic origin, followed by immobilizing the complexes on dietary fiber of wheat bran. Mixed-ligand systems were obtained by combining a metabolite (lactic acid) and degradation products of peptidoglycans of Lactobacillus delbrueckii subsp. Bulgaricus B-3964. The peptidoglycans of the biomass autolysate were degraded by enzymatic hydrolysis with papain. This resulted in obtaining a mixture that contained amino acids, low molecular weight peptides, and muropeptides, in the concentrations $12.44 \mathrm{mg} / \mathrm{cm}^{3}, 6.85 \mathrm{mg} / \mathrm{cm}^{3}$, and $2.76 \mathrm{mg} / \mathrm{cm}^{3}$, respectively. The nephelometric method has shown that this mixed-ligand system binds calcium ions in an amount of $18 \mathrm{mg} / \mathrm{cm}^{3}$. The soluble complexes obtained were immobilized on the dietary fiber to solve the problem of concentrating, drying, and dosing these ingredients. It has been proved that immobilization only occurs due to physical sorption that completely releases the active component from the dietary fiber matrix under conditions that simulate the gastrointestinal environment. The functional ingredient developed was added to the classic wheat bread recipe, where it replaced $1 \%, 3 \%$, and $5 \%$ of the flour. Bread was made without pre-fermentation to reduce the total production time and to prevent the ingredient's biologically active components from being assimilated by yeast during long fermentation. The study of the experimental and control samples of wheat bread has shown that the introduction of chelate complexes of calcium immobilized on dietary fiber causes no deterioration of the physico-chemical parameters of the finished bread: they are all within the limits approved by the regulatory documentation. The sensory properties of the samples with $1 \%$ and $3 \%$ of flour replaced are close to those of the control sample. So $3 \%$ of the ingredient is the recommended amount to be added, as it provides $98 \%$ of the daily requirement of calcium as a functional ingredient and covers about $25 \%$ of the daily allowance of dietary fiber.

Key words: wheat bread, functional ingredient, calcium, chelate complexes, bioligands, peptidoglycans, probiotic bacteria, dietary fiber.

\section{Хліб пшеничний функціонального призначення з вмістом хелатних форм кальцію}

\author{
А. I. Капустян, Н. К. Черно, Т. Лебеденко
}

Одеська національна академія харчових технологій, м. Одеса, Украӥна

Перспективними об'єктами для збагачення функціональними харчовими інгредієнтами є хлібобулочні вироби, оскільки ие продукти масового вжитку. Враховуючи проблему гіпоелементозів у населення, доцільним є розроблення функціональних харчових інгредієнтів на основі легкозасвоюваних та безпечних форм есенційних біометалів, в тому числі, кальцію. У роботі обгрунтовано можливість збагачення хліба пшеничного хелатними комплексами кальцію, які отримували шляхом комплексоутворення Са ${ }^{2+}{ }_{3}$ біолігандами пробіотичного походження з наступною іммобілізачією комплексів на харчових волокнах пшеничних висівок. Змішанолігандні системи отримували иляхом поєднання метаболіту, а саме, молочної кислоти, та продуктів деградації пептидо- 
гліканів Lactobacillus delbrueckii subsp. Bulgaricus B-3964. Деградацію пептидогліканів проводили за допомогою ферментолізу папаӥном автолізату біомаси. У результаті чого отримали суміш, щуо містить амінокислоти, низькомолекулярні пептиди та

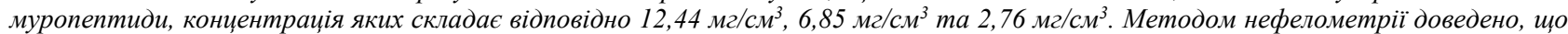
дана зміманолігандна система зв'язує йони кальцію у кількості 18 мг/см‥ Іммобілізацію отриманих розчинних комплексів на харчових волокнах здійснювали з метою подолання проблеми концентрування, сушіння та дозування даних інгредієнтів. Доведено, цзо іммобілізація відбувається лиме за рахунок фізичної сорбиії, щуо обумовлює повне вивільнення активної складової із матриці харчових волокон в умовах, щзо імітують середовища шлунково-кишкового тракту. Розроблений функціональний харчовий інгредієнт додавали до класичної рецептури хліба пшеничного, замінюючи 1 \%, 3 \% та 5 \% борошна. Хліб готували безопарним способом з метою скорочення загального часу виробництва хліба, а також унеможливлення ймовірної асиміляиії біологічно активних складових функиіонального харчового інгредієнту дріжджами при тривалому бродінні. Встановлено, щуо внесення іммобілізованих хелатних комплексів кальцію не приводить до погіриення фізико-хімічних показників готового хліба, вони всі знаходяться в межах, затверджених нормативною документацією. Сенсорні властивості зразків із заміною 1 \% та 3 \% борошна наближаються до показників контрольного зразка, тому рекомендованою кількістю для внесення функціонального інгредієнта є саме 3 \%, оскільки при цььому забезпечується 98 \% від добової норми кальцію як функціонального інгредієнта та покривається близько $25 \%$ добової норми харчових волокон, якщо вживання продукту складає рекомендовану добову норму 280 г.

Ключові слова: хліб пшеничний, функціональний інгредієнт, кальиій, хелатні комплекси, біоліганди, пептидоглікани, пробіотичні бактеріі, харчові волокна.

\section{Вступ}

Сучасною світовою тенденцією у галузі харчових технологій $\epsilon$ розроблення продуктів харчування підвищеної харчової цінності, які здатні впливати на фізіологічні процеси в організмі людини, в тому числі, стимулювати і покращувати опірність до різних захворювань, підвищувати імунітет (Simakhina \& Naumenko, 2016; Cherevko \& Peresichniy, 2017; Aguilar-Toalá et al., 2018). Для досягнення таких ефектів до складу продуктів вводять функціональні інгредієнти, які мають певні фізіологічні ефекти.

Викликає інтерес введення таких інгредієнтів до складу хлібобулочних виробів, які є стратегічними продуктами масового вжитку (Oliinyk et al., 2014; Pavlenko, 2014). Незважаючи на досить широкий вітчизняний асортимент цих виробів, частка функціональних в загальному об'ємі їхнього виробництва не перевищує 1-2 \% (Arsenieva et al., 2005; Dubinina et al., 2016).

Хлібобулочні вироби та хліб займають одне з перших місць в сучасних раціонах харчування населення, що майже на половину задовольняють потреби людини у вуглеводах, білках, вітамінах групи В, солях фосфору і заліза. Ці продукти лежать в основі піраміди харчування людини, проте їх хімічний склад $\epsilon$ недосконалим і потребує збільшення кількості найважливіших для організму нутрієнтів та їх збалансованості (Drobot, 2006). Саме тому доцільно вдосконалювати та розширювати асортимент хлібобулочних виробів та хліба. Розроблення хліба функціонального призначення $\epsilon$ сучасною нагальною проблемою. Ї̈ вирішенню присвячено ряд робіт вітчизняних (Oliinyk et al., 2014; Pavlenko, 2014; Dubinina et al., 2016) та зарубіжних (Ibrahim et al., 2015; Sirbu \& Arghir, 2017; Tarazona et al., 2018) вчених.

Беручи до уваги поширення випадків гіпоелементозів у населення (Karkischenko, 2013; Goff, 2018), доцільним $\epsilon$ збагачення продуктів масового вжитку безпечними та ефективними формами есенційних біометалів, зокрема, кальцієм. Йони $\mathrm{Ca}^{2+}$ необхідні для формування кісткової тканини, у процесі лактації, при реалізації серцевих скорочень, а також вони $є$ фактором згортання крові, активізують ряд ферментів і т.д. (Marth, 2008; Skalny \& Skalnaya, 2011).
Біометали у складі неорганічних сполук при потраплянні в організм 3 їжею володіють рівнем біодоступності не більше 2-20\% (Goff, 2018). Підвищення біодоступності мікроелементів - одна 3 актуальних задач сучасної науки. Сьогодні існує особливий інтерес до профілактики та лікування багатьох гіпомікроелементозів за допомогою біокоордінаціонних сполук, в яких життєво необхідні мікроелементи містяться в вигляді хелатного комплексу з біолігандами природними носіями мікроелементів (Skalny \& Skalnaya, 2011; Karkischenko, 2013; Abdel-Mottaleb \& Ismail, 2019).

Для отримання хелатних комплексів кальцію, перспективним $\epsilon$ використання у якості лігандів продуктів метаболізму та переробки пробіотичних культур (Kapustian et al., 2018), а саме, молочної кислоти та продуктів деградації пептидогліканів клітинних стінок - амінокислот, низькомолекулярних пептидів та муропептидів. Використання зазначених сполук для комплексоутворення забезпечить утворення стабільних комплексів, оскільки дані системи є змішанолігандними та полідентантними, що забезпечить високу енергію зв'язків (Skalny \& Skalnaya, 2011; Karkischenko, 2013). Отримання хелатних форм кальцію з біолігандами пробіотичного походження може забезпечити мультивекторність функціонального продукту, адже продукти деструкції пептидогліканів, а саме муропептиди, володіють потужною імунотропною активністю (Cherno \& Kapustyan, 2016; Irazoki et al., 2019).

У світовій науковій літературі відсутні дані щодо можливості використання хелатних комплексів кальцію 3 біолігандами пробіотичного походження як функціональних інгредієнтів хлібобулочних виробів, та їхнього впливу на фізико-хімічні та сенсорні характеристики продукту.

Тому метою роботи було розроблення рецептури та технології хліба пшеничного функціонального призначення з вмістом хелатних комплексів кальцію.

Завдання досліджень:

1. Обгрунтування принципової схеми отримання функціонального харчового інгредієнту на основі хелатних комплексів кальцію з біолігандами пробіотичного походження. 
2. Обгрунтування рецептури та принципової схеми технології хліба пшеничного функціонального призначення.

3. Дослідження фізико-хімічних та сенсорних характеристик хліба пшеничного функціонального призначення.

\section{Матеріал і методи досліджень}

Матеріали досліджень: для досліджень використовували біомасу (БМ) молочнокислих бактерій Lactobacillus delbrueckii subsp. Bulgaricus B-3964 концентрацією 4,8 $10^{9} \mathrm{KУO} / \mathrm{cm}^{3}$ із колекції НВП “Аріадна”, м. Одеса, папаїн із протеолітичною активністю 10 Од/мг (Swanson Health Products, США), $\mathrm{CaCl}_{2}$ "ч" (Китай), харчові волокна пшеничних висівок (ХВПВ) (Фармаком, м. Харків, Україна).

Отримання продуктів деструкиії пептидогліканів Lactobacillus delbrueckii subsp. Bulgaricus B-3964. Для попередньої дезінтеграції бактеріальних клітин проводили їхній автоліз при $50{ }^{\circ} \mathrm{C}$ протягом 144 год (Kapustian et al., 2018). Виділення дезінтегрованих клітин з культуральної рідини здійснювали шляхом центрифугування протягом 15 хв при $8000 \mathrm{xB}^{-1}$. Осад клітин відмивали дистильованою водою, ресуспендували та направляли на ферментоліз. Ферментативну деструкцію автолізату клітинних стінок БМ здійснювали обробкою папаїном за температури $37^{\circ} \mathrm{C}$ та $\mathrm{pH}=$ 5,5. Співвідношення фермент : субстрат (вміст сухих речовин БМ) складало $1: 200$, тривалість інкубації реакційної суміші - 300 хв (Kapustian et al., 2018). Ферментоліз зупиняли екстреним нагріванням до температури $100{ }^{\circ} \mathrm{C}$, суміш охолоджували, відокремлювали рідку фазу від твердої шляхом центрифугування протягом 10 хв при $8000 \mathrm{xB}^{-1}$. У рідкий фазі контролювали вміст вільних амінокислот методом формольного титрування (Semak et al., 2007). Вміст низькомолекулярних пептидів (НМП) визначали методом Бенедикта (Semak et al., 2007) після осадження високомолекулярних білків $10 \%$-вим розчином трихлороцтової кислоти, вміст муропептидів визначали після очищення ферментолізату на іонообмінній колонці з катіонітому КУ-2 та подальшим визначенням вуглеводної складової у складі муропептидів Антроновим методом (Morris, 1948; Kapustian et al., 2019).

Виділення молочної кислоти із супернатанту проводили класичним методом, що включає кристалізацію кальцію лактату з послідуючою обробкою кристалів сульфатною кислотою та видаленням нерозчинного осаду кальцію сульфату (Starr \& Westhoff, 2014).

Комплексоутворення. Комплекси отримували поєднанням розчинів ферментолізату Lactobacillus delbrueckii subsp. Bulgaricus B-3964, молочної кислоти (концентрація у суміші $10 \mathrm{Mr} / \mathrm{cm}^{3}$ ) та $\mathrm{CaCl}_{2}$ при інтенсивному перемішуванні протягом 180 с, температура комплексоутворення складала $40{ }^{\circ} \mathrm{C}$. Комплексоутворювальну здатність іонів металів по відношенню до біолігандів визначали нефелометричним методом в присутності $\mathrm{Na}_{2} \mathrm{CO}_{3}$ на спектрофотометрі СФ-2000 за довжини хвилі 450 нм (Kapustian \& Cherno, 2019).
Отримання функціонального харчового інгредієнmy (ФXI). ФXI отримували шляхом іммобілізації отриманих комплексів кальцію на ХВПВ. ХВПВ попередньо позбавляли від залишків водо- та солерозчинних білків шляхом трикратної обробки фізіологічним розчином $\mathrm{NaCl}$ при гідромодулі (ГМ) $1: 20$ (суміш перемішували протягом 10 хв за кімнатної температури). ХВПВ відмивали дистильованою водою та висушували у конвективній сушарці за температури $70{ }^{\circ} \mathrm{C}$ до досягнення вологості 10-12 \%. Іммобілізацію проводили шляхом поєднання розчину органічного комплексу біометалу 3 ХВПВ (гідромодуль (ГМ) $1: 5)$. Суміш витримували 120 хв та висушували у конвективній сушарці за температури $50{ }^{\circ} \mathrm{C}$ до досягнення вологості 10-12 \%. На рис. 1 наведено принципову схему отримання ФХІ на основі комплексів біометалів зі сполуками пробіотичного походження та ХВПВ.

Визначення ступеню десорбиї комплексу з матриuзi ХВПВ. Ступінь десорбції комплексу кальцію із матриці визначали шляхом індикації кількості білкових речовин комплексу, що перейшли у зовнішнє середовище екстрагенту від загального вмісту цих речовин у комплексі (\%) реакцією 3 нінгідрином (Semak et al., 2007). Для визначення ступеня десорбції органічних комплексів біометалів із ХВПВ у якості екстрагентів використовували воду дистильовану (ГМ $1: 5$, тривалість процесу 300 хв) та буферні системи, що відповідають $\mathrm{pH}$ середовищам відділів шлунковокишкового тракту (ШКТ), а саме, шлунку (рН 1,2) та тонкого кишківника (pH 7,4). ФХІ витримували 120 хв у розчині 3 рН 1,2 при ГМ $1: 5$, після чого відділяли рідку фазу, до осаду додавали буфер $3 \mathrm{pH}$ 7,4 та інкубували суміш протягом 180 хв при перемішуванні. Концентрацію білкових речовин у рідкій фазі суміші визначали через кожні 30 хв.

Приготування хліба функціонального призначення. Тісто для пробного лабораторного випікання готували безопарним способом згідно рецептури, вказаної в табл. 1 (Drobot, 2006). Готували чотири зразки хліба: контрольний, із заміною $1 \%, 3 \%$ та $5 \%$ борошна на ФXI.

ФХІ додавали до борошна та ретельно перемішували для рівномірного його розподілення по всьому об'єму. Поєднували усі рецептурні інгредієнти, замішували тісто. Вистоювання тістових заготовок проводили за температури $(37 \pm 2){ }^{\circ} \mathrm{C}$ і відносної вологості $(75 \pm 2) \%$ до готовності. Вироби випікали в шафовій печі за температури $180-250{ }^{\circ} \mathrm{C}$.

Відбір проб готових хлібобулочних виробів і оцінку їх органолептичних показників (зовнішній вигляд, колір і стан скоринки, стан м'якушки, смак, запах) здійснювали за ДСТУ 7044:2009 не раніше ніж через $180 \times 60$ с після їхнього повного остигання. Фізикохімічні показники якості (масову частку вологи, кислотність, пористість та питомий об’єм) визначали за стандартними методиками за ДСТУ 7045:2009. 


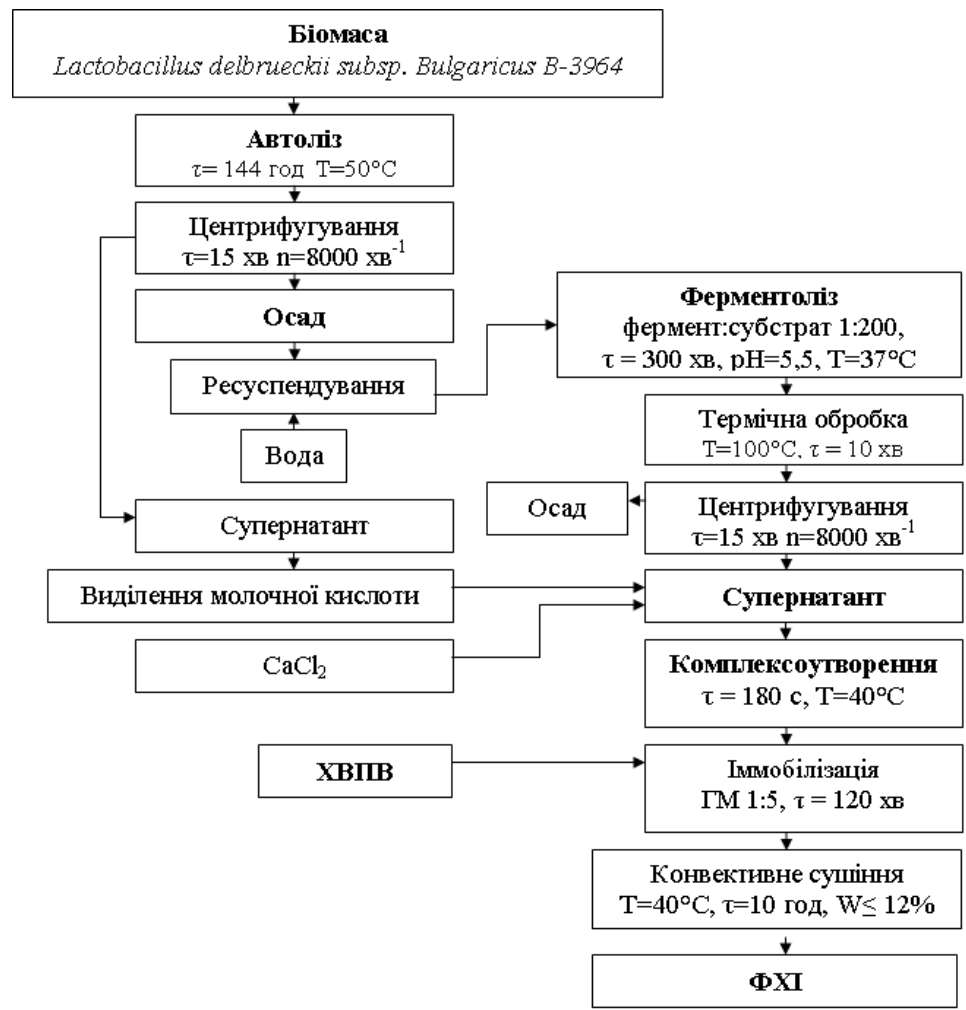

Рис. 1 Схема отримання ФХІ на основі комплексів $\mathrm{Ca}^{2+}{ }_{3}$ біолігандами пробіотичного походження та ХВПВ

\section{Таблиця 1}

Рецептурні компоненти хліба функціонального призначення

\begin{tabular}{lcccc}
\hline \multirow{1}{*}{ Найменування сировини } & \multicolumn{3}{c}{ Витрати компонентів рецептури, г } \\
\cline { 2 - 5 } Борошно пшеничне І гатунку & Контроль & Зразок 1 & Зразок 1 & 3разок 1 \\
\hline ФХІ & 975,0 & 965,0 & 945,0 & 925,0 \\
Розчин солі & - & 60,0 & 60,0 & 60,0 \\
Дріжджова суспензія & 60,0 & 40,0 & 40,0 & 40,0 \\
Рідкі дріжджі & 40,0 & 100,0 & 100,0 & 100,0 \\
Підсумок & 100,0 & 1175,0 & 1175,0 & 1175,0 \\
Вода & 1175,0 & 454,0 & 454,0 & 454,0 \\
Разом (тіста) & 454,0 & 1629,0 & 1629,0 & 1629,0 \\
\hline
\end{tabular}

\section{Результати та їх обговорення}

Для утворення хелатних комплексів кальцію використовували біоліганди пробіотичного походження, а саме, продукти деструкції пептидоглікану Lactobacillus delbrueckii subsp. Bulgaricus B-3964. Деструкцію пептидоглікану клітинних стінок біомаси (БМ) проводили за процедурою, наведеною вище. У результаті, отримали суміш амінокислот, НМП та муропептидів, концентрація яких складає відповідно

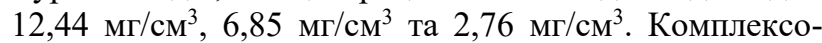
утворювальну ємність змішанолігандної системи по відношенню до кальцію досліджували методом нефелометрії, а саме, шляхом детекції нерозчинних форм кальцію карбонату, які утворюються при взаємодії вільних йонів $\mathrm{Ca}^{2+} 3$ натрієм карбонатом після насичення системи лігандів біометалом і провокують помутніння. Результати дослідження наведено на рис. 2.

Як видно 3 рис. 2, мутність змішанолігандної систем в присутності йонів $\mathrm{Ca}^{2+}$ та $\mathrm{Na}_{2} \mathrm{CO}_{3} \epsilon$ мінімально стабільною (0,04 опт. од.) до досягнення в суміші певної концентрації металу. Так, стрімкий ріст мутно- сті системи має місце за концентрації $\mathrm{Ca}^{2+}$ у суміші у кількості $18 \mathrm{мг} / \mathrm{cm}^{3}$. Така поведінка досліджуваної системи свідчить про те, що до досягнення даної концентрації, метал знаходиться у зв'язаному стані у складі змішанолігандних комплексів, що унеможливлює його взаємодію 3 присутнім у системі натрієм карбонатом та появу нерозчинних частинок кальцію карбонату, які й обумовлюють помутніння системи.

Раніше було доведено (Kapustian et al., 2018), що органічні комплекси кальцію з біолігандами пробіотичного походження є стабільними в широкому інтервалі $\mathrm{pH}$ (2-10 од.) та температур (40-180 $\left.{ }^{\circ} \mathrm{C}\right)$, що дозволило рекомендувати їх у якості функціональних харчових інгредієнтів для продуктів харчування, технологія яких передбачає високотемпературну обробку.

Оскільки умови отримання комплексів кальцію 3 біолігандами пробіотичного походження передбачають використання розбавлених розчинів їхніх складових, при розробленні технологій дієтичних добавок та харчових інгредієнтів на їхній основі, виникають проблеми концентрування та сушіння таких систем. 
При отриманні розчинних хелатних комплексів за пропонованою схемою, вміст вологи може складати до 95 \%. Дані системи важко піддаються сушінню та є досить гідрофільними після висушування, що ускладнює їхнє зберігання та можливе дозування при додаванні до харчових систем. Окрім того, зважаючи на те, ефективні добові норми отриманих комплексів є досить низькими, може виникати проблема рівномірного розподілу такого функціонального харчового інгредієнту по всьому об'єму продукту. Із метою позбавлення таких недоліків, запропоновано проводити іммобілізацію отриманих комплексів на класичних матрицях - харчових волокнах пшеничних висівок (ХВПВ). Іммобілізацію проводили шляхом поєднання ХВПВ та розчину хелатного комплексу кальцію при ГМ $1: 5$. Оскільки в $1 \mathrm{~cm}^{3}$ розчину міститься 18 мг $\mathrm{Ca}^{2+}$ (рис. 2), то після його сорбції на харчових волокнах, вміст хелатного комплексу Кальцію в 1 г ФХІ після висушування складатиме 90 мг.

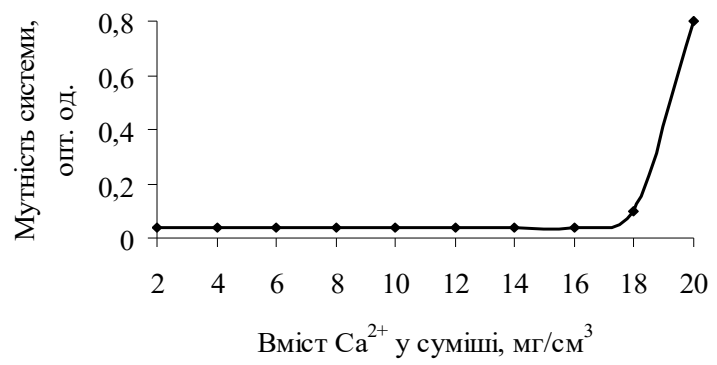

Рис. 2. Залежність мутності змішанолігандної системи пробіотичного походження від вмісту йонів біометалів у присутності $\mathrm{Na}_{2} \mathrm{CO}_{3}$

Доцільним на наступному етапі було встановлення закономірності десорбції комплексу $\mathrm{Ca}^{2+}$ із матриці ХВПВ при експозиції ФХІ у воді та розчинах, $\mathrm{pH}$ яких відповідають рН відділів ШКТ (рис. 3).

Характер вивільнення комплексу із ХВПВ при експозиції у воді дистильованій та розчинах, що відповідають рН відділів ШКТ, дещо відрізняється. Більш інтенсивно відбувається десорбція комплексу при інкубації ФХІ у воді, повне його вивільнення має місце після 210 хв екстрагування. Десорбція органічної форми кальцію при екстрагуванні розчинами, що відповідають рН відділів ШКТ, у перші 120 хв інкубації відбувається доволі повільно (всього $35 \%$, на противагу експерименту з водою - 75 \%). Повне вивільнення комплексу має місце після 270 хв експозиції. Повільну десорбцію комплексу при низьких значеннях $\mathrm{pH}$ середовища (перші 120 хв експерименту) можна пояснити низькою водозв'язувальною здатністю ХВПВ за даних умов, що $є$ певною перешкодою для вивільнення комплексу. Оскільки десорбція комплексу була повною, то можна припустити, що іммобілізація відбувається лише за рахунок фізичної сорбції. Час повної десорбції комплексу біометалу з ХВПВ в обох експериментах відповідає уявленням щодо тривалості процесу транспортування харчової грудки із верхніх відділів ШКТ до місця поглинання біметалів ентероцитами тонкого кишківника.

Результати досліджень свідчать що отриманий ФХІ є перспективним компонентом хлібобулочних виробів, оскільки є термостабільним, стійким за $\mathrm{pH} 2$ та 8, які характерні для відділів травного тракту людини, та повністю десорбується з матриці.

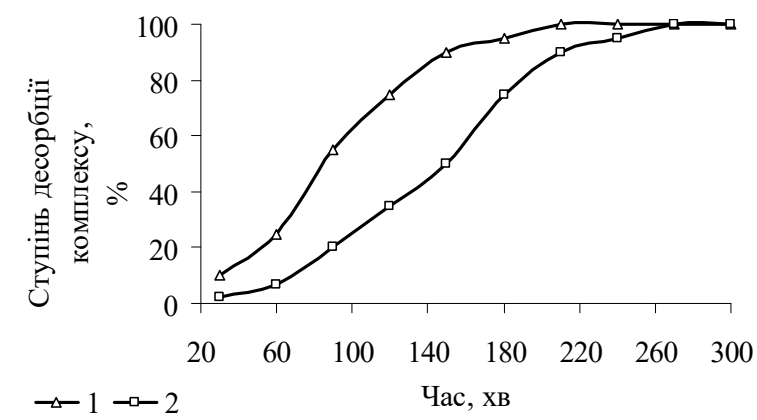

Рис. 3. Десорбція комплексу $\mathrm{Ca}^{2+}{ }_{3} \mathrm{XBПВ:}$

крива 1 характеризує десорбцію при експозиції комплексу у воді, крива 2 - у розчинах, що емітують pH середовища відділів ШКТ

При введенні фізіологічно-функціонального інгредієнту у харчовий продукт, виникає проблема збереження фізико-хімічних та сенсорних характеристик останнього. Це зумовило доцільність визначення відповідних показників дослідних зразків хліба.

Згідно процедури, описаної в розділі “Матеріали та методи досліджень”, отримували контрольний та три дослідних зразки хіба, фізико-хімічні властивості яких наведено в табл. 2, сенсорні характеристики - на рис. 4.

\section{Таблиця 2}

Фізико-хімічні показники дослідних зразків хліба

\begin{tabular}{lcccc}
\hline \multicolumn{1}{c}{ Показник } & Зразок № 1 & Зразок № 2 & 3разок № 3 & ДСТУ 7517:2014 \\
\hline Об’єм хліба, см ${ }^{3}$ & 770 & 840 & 700 & Не нормується \\
Питомий об’єм, см ${ }^{3} 100$ г & 408 & 381 & 373 & Не нормується \\
Формостійкість, H/D & 0,5 & 0,41 & 0,33 & Не нормується \\
Пористість, \% & 65 & 63 & 60,5 & Не менше ніж 63,0 \\
Вологість, \% & 44,3 & 44,6 & 44,3 & Не більше ніж \\
Кислотність, град & 2,2 & 2,2 & 2,2 & Н9,0-48,0 більше ніж \\
\end{tabular}




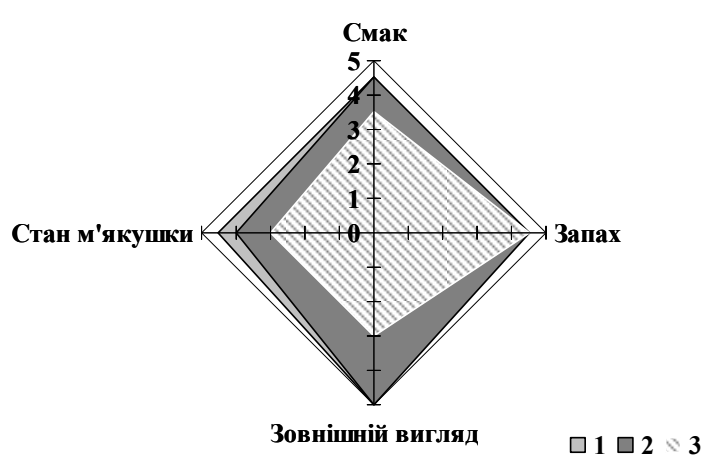

Рис. 4. Сенсорні характеристики дослідних зразків хліба

Результати досліджень дозволяють констатувати, що усі зразки хліба відповідають нормативнотехнічній документації за фізико-хімічними показниками (ДСТУ7 517:2014). Згідно даних сенсорної оцінки дослідних зразків, найкращим за загальним балом $є$ зразок 1 , але беручи до уваги рецептурний склад, то зразок 2 містить більшу кількість біологічно активних компонентів при незначній відмінності загального балу органолептичної оцінки зразка 1.

Проведені дослідження дозволяють обгрунтувати принципову технологічну схему виробництва хліба функціонального призначення 3 вмістом хелатних форм кальцію (форма - подова, вага 500 г) (рис. 5). Під час виробництва хліба функціонального призна- чення повинна виконуватися певна послідовність дій. На першому етапі проводиться перемішування борошна та ФХІ для його рівномірного розподілення по всьому об'ємі борошна та, відповідно, хліба. Після ретельного перемішування борошна та ФХІ додаються рецептурні інгредієнти (табл. 1). Після того як до суміші додали усі супровідні інгредієнти, проводиться перемішування тіста за допомогою тістомісильних машин протягом 25 хв, після остаточного вимішування, тісто залишають дозрівати при температурі $30{ }^{\circ} \mathrm{C}$ протягом 120 хв. Безопарний спосіб виробництва хліба дозволяє скоротити загальний час виробництва хліба, а також унеможливлює ймовірну асиміляцію біологічно активних складових ФХІ дріжджами при тривалому бродінні. Наступним етапом $є$ формування заготовки, та повторне вистоювання протягом 20 хв при температурі $30^{\circ} \mathrm{C}$. Випікання проводиться у 3 етапи, перший - 4 хв за температури $250{ }^{\circ} \mathrm{C}$, при цьому відбувається формування скоринки, після чого йдуть два наступні етапи, націлені на пропечення тістової заготовки з середини, їхня тривалість складає 25 та 20 хв за температури 230 і $180^{\circ} \mathrm{C}$. Після випікання хліб охолоджують.

Отже, якщо у рецептуру хліба функціонального призначення включити ФХІ у кількості $3 \%$ (дослідний зразок 2), то його вміст у готовому виробі складатиме 30 г (табл. 1) на 1600 г готового хліба (враховуючи середні витрати на випікання (Drobot, 2006)).

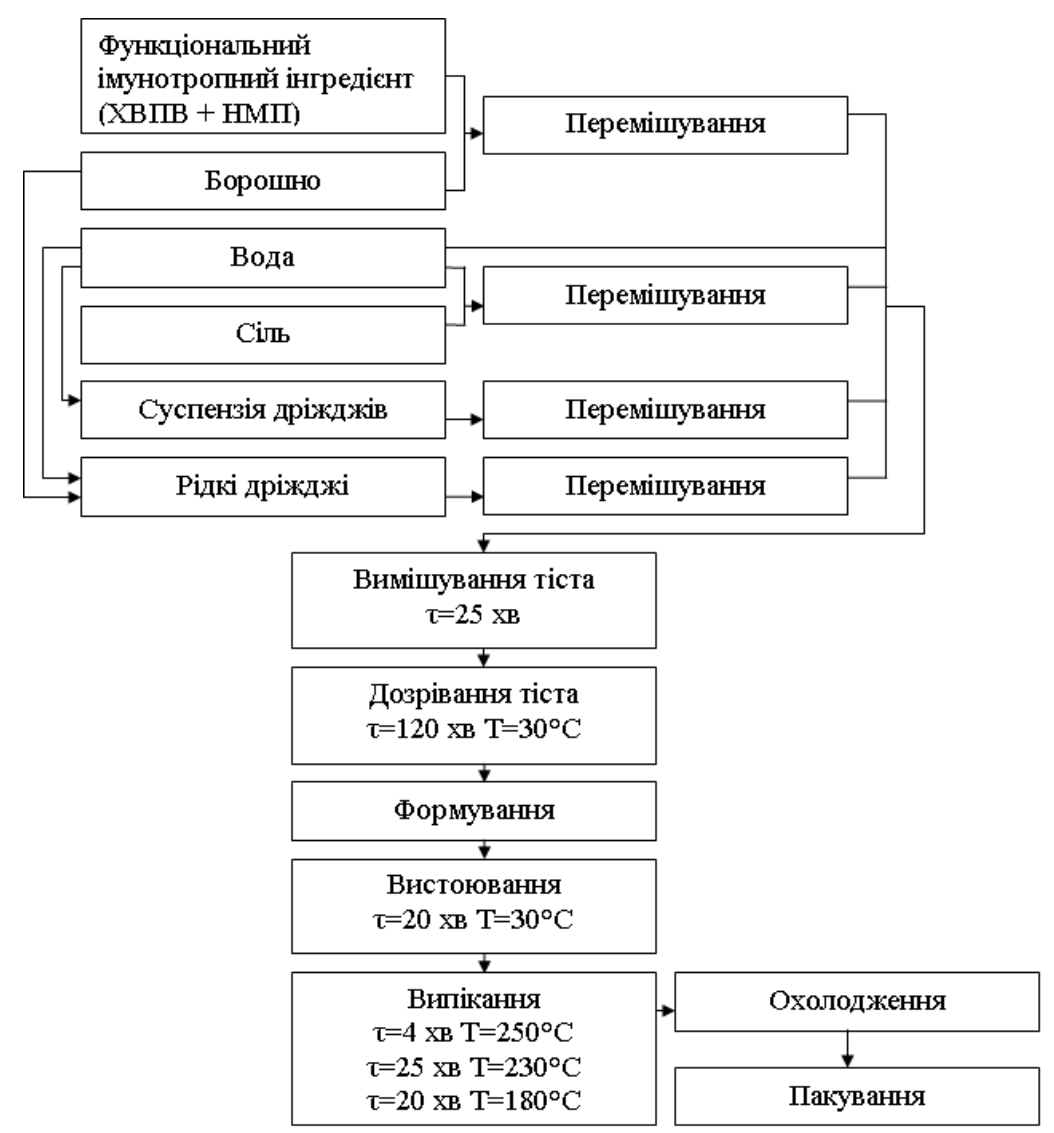

Рис 5. Принципова технологічна схема виробництва хліба функціонального призначення з вмістом хелатних форм кальцію 
Оскільки, згідно Постанови Кабінету міністрів України № 780 від 11.10.2016 р. “Про затвердження наборів продуктів харчування, наборів непродовольчих товарів та наборів послуг для основних соціальних і демографічних груп населення", норма споживання для дорослого населення хліба житнього складає 38 кг, а пшеничного - 62 кг, то середня рекомендована добова норма вживання хліба при цьому складає близько 280 г. Отже, при вживанні даної кількості хліба функціонального призначення, споживач отримує 5,25 г ФХІ. Оскільки вміст вміст кальцію у його складі 90 мг на 1 г, то у середньодобовій нормі хліба міститься, відповідно, 472,5 мг даного біометалу. Зважаючи на те, що згідно Наказу № 1073 від 03.09.2017 "Про затвердження Норм фізіологічних потреб населення України в основних харчових речовинах і енергіï” середня добова потреба дорослої людини у кальції становить 1100-1200 мг, а функціональні продукти мають задовольняти 40 \% від добової потреби будь-якого нутрієнта (Nechaev et al., 2001), то рекомендована добова доза кальцію у складі функціональних продуктів складає 480 г. Отже, при вживанні 280 г хліба функціонального, покривається 98 \% кальцію, який рекомендовано вживати у складі функціональних продуктів харчування. Окрім того, забезпечується 7,2 \% від добової потреби у харчових волокнах (Nechaev et al., 2001).

\section{Висновки}

Обгрунтувано принципову схему отримання функціонального харчового інгредієнту на основі хелатних комплексів кальцію з біолігандами пробіотичного походження Розроблено рецептуру та технологію хліба пшеничного функціонального призначення 3 вмістом хелатних комплексів кальцію. Фізикохімічні показники готового хліба функціонального призначення, знаходяться в межах, затверджених нормативною документацією. Сенсорні властивості зразків із заміною $1 \%$ та 3 \% борошна наближаються до властивостей контрольного зразка. Рекомендованою кількістю внесення функціонального інгредієнта у харчову систему є $3 \%$, що забезпечує $98 \%$ від добової потреби кальцію та покриває близько 25 \% добової потреби харчових волокон при вживанні 280 г хліба.

\section{References}

Abdel-Mottaleb, M. S. A., \& Ismail, E. H. (2019). Transition Metal Complexes of Mixed Bioligands: Synthesis, Characterization, DFT Modeling, and Applications. Journal of Chemistry, 2019, Article ID 3241061, 18. doi: 10.1155/2019/3241061.

Aguilar-Toalá, J. E., Garcia-Varela, R., Garcia, H. S., Mata-Haro, V., González-Córdova, A. F., VallejoCordoba, B., \& Hernández-Mendoza, A. (2018). Postbiotics: An evolving term within the functional foods field. Trends in Food Science \& Technology, 75, 105-114. doi: 10.1016/j.tifs.2018.03.009.

Arsenieva, L. Iu., Herasymenko, L. O., Derevianko, L. P., Antoniuk, M. M., \& Khivrych, B. I. (2005). inventor;
Natsionalnyi universytet kharchovykh tekhnolohii, assignee. Pshenychnyi khlib funktsionalnoho pryznachennia. Ukrainian ptent 4512. 17.01.2005. http:/uapatents.com/10-4512-pshenichnijj-khlibfunkcionalnogo-priznachennya.html (in Ukrainian).

Cherevko, O. I., \& Peresichniy, M. I., (2017). Innovatsiini tekhnolohii kharchovoi produktsii funktsionalnoho pryznachennia: monohrafiia. Chastyna 1. 4-te vyd., pererobl. ta dopov. Kh.: Kharkivskyi derzh. univ. kharchuv. i torhivli (in Ukrainian).

Cherno, N., \& Kapustyan, A. (2016). Immunological properties of the bacterial origin compounds. Food science and technology, 10(3), 19-28. doi: 10.15673/fst.v10i3.175.

Drobot, V. I. (2006). Tekhnolohiia khlibopekarskoi vyrobnytstva. K.: Lohos (in Ukrainian).

Dubinina, A., Lenert, S., \& Popova, T. (2016). Vykorystannia pshona u vyrobnytstvi khliba ozdorovchoho pryznachennia. Food Science and Technology, 10(4), 18-24. doi: 10.15673/fst.v10i4.249 (in Ukrainian).

Goff, J. P. (2018). Invited review: Mineral absorption mechanisms, mineral interactions that affect acid-base and antioxidant status, and diet considerations to improve mineral status. Journal of Dairy Science, 101(4), 2763-2813. doi: 10.3168/jds.2017-13112.

Ibrahim, U. K., Salleh, R. M., \& Maqsood-ul-Haque, S. N. S. (2015). Bread towards Functional Food: An Overview. International Journal of Food Engineering, 1(1), 39-43. doi: 10.18178/ijfe.1.1.39-43.

Irazoki, O., Hernandez, S.B., \& Cava, F. (2019). Peptidoglycan Muropeptides: Release, Perception, and Functions as Signaling Molecules. Front. Microbiol., 10, 500. doi: 10.3389/fmicb.2019.00500.

Kapustian, A. I., \& Cherno, N. K. (2019). Vyznachennia kompleksoutvoriuvalnoi zdatnosti zmishanolihandnykh orhanichnykh system po vidnoshenniu do yoniv metaliv. Naukovyi visnyk Lvivskoho natsionalnoho universytetu veterynarnoi medytsyny ta biotekhnolohii im. S. Z. Hzhytskoho, 21(91), 130135. doi: 10.32718/nvlvet-f9122 (in Ukrainian).

Kapustian, A. I., Cherno, N. K., \& Pukas, A. S. (2019). Rozroblennia metodu vyznachennia funktsionalnykh kharchovykh inhrediientiv muropeptydnoho pokhodzhennia u bakterialnykh dezintehratakh. Naukovi pratsi NUKhT, 25(62), 157-164. doi: 10.24263/2225-2924-2019-25-6-21 (in Ukrainian).

Kapustian, A., Cherno, N., \& Nikulina, O. (2018). Obtaining and characteristics of calcium organic forms on the basis of metabolites and processing products of probiotic bacteria. Food Science and Technology, 12(2), 4-12. doi: 10.15673/fst.v12i2.944.

Karkischenko, N. N. (2013). Rol mikroelementov v sportivnom pitanii $\mathrm{i}$ bezopasnost metallohelatov. Biomeditsina, 2, 12-41 (in Russian).

Marth, J. D. (2008). A unified vision of the building blocks of life. Nat Cell Biol., 10(9), 1015-1016. doi: 10.1038/ncb0908-1015.

Morris, D. L. (1948). Quantitative Determination of Carbohydrates With Dreywood's Anthrone Reagent. Science, 107(2775), 254-255. doi: 10.1126/science. 107.2775.254. 
Nechaev, A. P., Traubenberg, S. E., \& Kochetkova, A. A. (2001). Pischevaya himiya. S.-Pb.: GIORD (in Russian).

Oliinyk, S. H., Lysiuk, H. M., Kravchenko, O. I., \& Samokhvalova, O. V. (2014). Tekhnolohii khlibobulochnykh vyrobiv iz produktamy pererobky zarodkiv pshenytsi. Kh.: KhDUKhT (in Ukrainian).

Pavlenko, A. A. (2014). Zbahachennia khlibobulochnykh vyrobiv spetsialnoho pryznachennia vitaminom D. Tekhnolohycheskyi audyt y rezervi proyzvodstva, 6/1(20), 36-39. doi: 10.15587/2312-8372.2014.31511 (in Ukrainian).

Semak, I. V., Zyiryanova, T. N., \& Gubich, O. I. (2007). Biohimiya belkov: praktikum dlya studentov biol. Fak. spets. 1-31 0101 "Biologiya". Minsk: BGU (in Russian).

Simakhina, H. O., \& Naumenko, N. V. (2016). Kharchuvannia yak osnovnyi chynnyk zberezhennia stanu zdorovia naselennia. Problemy starenyia i dolholetyia, 25(2), 204-214 (in Ukrainian).
Sirbu, A., \& Arghir, C. (2017). Functional bread: Effect of inulin-type products addition on dough rheology and bread quality. Journal of cereal science, 75, 220227. doi: $10.1016 /$ j.jcs.2017.03.029.

Skalny, A. V., \& Skalnaya, M. G. (2011). Metal ions as bioelements. Metal ions in biology and medicine, 11, 14.

Starr, J. N., \& Westhoff, G. (2014). Lactic Acid. Ullmann's Encyclopedia of Industrial Chemistry, Wiley. doi: 10.1002/14356007.a15 097.pub3.

Tarazona, L. K. J., Berbesi, C. M. A., Vera1, Y. C., Contreras-Velasquez, J. C., Bermudez, V., \& Rojas, E. (2018). A functional bread designed with rye flour and stevia sweetener: A sensory and microbiological analysis. Archivos Venezolanos de Farmacología y Terapéutica, 37(2), 129-134. https://search.proquest.com/openview/ cbe8ba134d939c7840ab8dd0ca58fbfd/1?pqorigsite $=$ gscholar\&cbl $=1216408$. 